\title{
Judit Baróthy
}

\section{'Intimacy which is knowledge': Fact and Fiction from a Feminist Point of View}

\author{
Nóra Séllei: \\ Katherine Mansfield and Virginia Woolf. A Personal and Professional Bond \\ (Debrecener Studien zur Literatur. Bd. 2) \\ Frankfurt am Main, etc: Peter Lang, 1996
}

The second publication of the two pillars that support the whole "Debrecener Studien Zur Literatur" building of the book: the numerous explores the biographical and literary links between two 'New Women', Virginia Woolf and Katherine Mansfield.

In the "Introduction" Séllei defines her aims and methods: her prime concern is to find the reasons for the "curious friendship" the "uneasy sisterhood" between the two writers, who are "after so very nearly the same thing." ${ }^{1}$ Séllei approaches the question from two different angles, from the personal and the professional points of view. These approaches are

${ }^{1}$ Mansfield quoted by Séllei, 35 chapters and subchapters are organised around two major sections, "Katherine and Virginia" and "Mansfield and Woolf". Séilei's investigation of both aspects makes use of the results of feminist literary criticism, especially of those feminist revisions of psychoanalytic theory which help her find the roots of the writers' practice in their childhood experiences (Nancy Chodorow, Dorothy Dinnerstein, Julia Kristeva, Adrienne Rich). Séllei, along with other feminist critics, argues that for women writers "to achieve artistic recognition required the double efforts of creating their 
identity both as individuals and as artists" (14) if they wanted to shake off the label 'feminine' attached to their work mainly by male critics. Thus their life, their struggle to escape from the prison of traditional femininity is inseparable from their literary achievement. The author also strives to find the reason why Mansfield has been neglected while Woolf's literary reputation has always been unquestionable. Feminist critics were the first to appreciate Mansfield's literary merits with due seriousness, but her reputation as a major Modernist, or even as a prominent woman writer, is still ambivalent. One of Séllei's declared aims is "to suggest that Katherine Mansfield, both as a self-conscious woman and as a female writer, represents an equally appropriate response to the same (human and aesthetic) situation" (14). She also argues that the two influential models these two 'foremothers' created in their lives, their theory and practice are combined by second wave feminist writers and theoreticians: "like Mansfield, they utter the previously unutterable experiences, but in a language that flows like Woolf's sentences." (19)

In the first section of her book Séllei examines the personal side of Katherine Mansfield and Virginia Woolf's relationship by contrasting their lives on different levels: she is equally interested in their "social and educational background, their psychological and psychosocial development, and the artistic models they follow" (23). Séllei herself admits that she is entering the marshland of subjectivity and claims that she is reconstructing "a true story" based on their thoughts of each other, expounded in their letters and diaries, which, although were often manipulated by rumours and prejudices, functioned as truth for Mansfield and Woolf: "they contributed to the opinion forming process, thus to their story." (23)

Despite the 'professional disagreement', which the author outlines in the second part, their friendship survived thanks to their mutual 'love of writing' and it appears that the happiest moments were when only the two of them discussed literature. However, these intimate 'chats' became less and less frequent due to Mansfield's serious illness. She suffered from consumption and sought a cure abroad. Séllei describes Mansfield's hopes and anguish, also increased by the death of her mother, and Woolf's attitude towards her illness, the compassion she felt for Mansfield and the irrational hatred she felt for Mansfield's husband, Murry. The complexity of their relationship was also marred by the feeling of jealousy on both sides: Mansfield envied 
Woolf's stable background provided by her husband, Woolf was jealous of Mansfield's success. Mansfield got favourable reviews for her three published volumes of short stories, while Woolf's first two novels (The Voyage Out and Night and Day) and two stories ("The Mark on the Wall" and "Kew Gardens") were not received with such enthusiasm. Woolf's attitude towards Mansfield remained ambivalent even after her rival's death. In her diary and private correspondence she often remembers her figure and their relationship: "We did not ever coalesce; but I was fascinated, and she respectful, only I thought her cheap, and she thought me priggish; and yet we were both compelled to meet simply in order to talk about writing."

Séllei also explores the differences in the writers' social and educational background that some critics (Antony Alpers, Claire Tomalin) consider responsible for the tensions in their friendship. She convincingly argues that these differences were not significant enough to lead to such serious disagreement. In her opinion "the greatest disparity in their friendship can be traced back to their different constitutions of their own womanhood.” (59)

\footnotetext{
${ }^{2}$ in a 1931 letter to Vita Sackville West, quoted by Séllei, 50
}

In her analysis of the two women's self-identification processes and relationship she employs theories of recent feminist revisions of psychoanalytic theory concerning the female child's psychosocial identification process (Nancy Chodorow, Julia Kristeva, and Elaine Showalter). Based mainly on her Journal, the author describes the adolescent self-creating period of Mansfield's life with its Wildean ideals and aspiration to be "more than a woman." These 'masculinely' individualistic ideals in the artistic sphere had a certain impact on her personal life, as well: though "she did not deny her femininity, she wanted to experience it to the full and required for herself the freedom granted for men." (15) Séllei continues with an analysis of Woolf's psyche to find the answer to the question why Woolf was so much irritated by Mansfield's character. She goes back to Woolf's early experiences, with a special emphasis on Woolf's relationship with her father and step-brothers after her mother's death, her "looking-glass shame", an early symptom of psychosexual disturbances. Her selfdenial, in Kristeva's terms, signals a refusal of the Oedipal phase. Séllei looks at Woolf's 'bouts of madness' "in the light of the conflict between the female self and the external patriarchal order." (78) Her argument is 
based on Gilbert and Gubar's interpretation of madness as an alternative existence for women in the nineteenth century, among other recent theories of Woolf's mental problems. By citing the thoughts and concepts of Woolf's doctors concerning mental disorder, she proves that their views were that of a hidebound conservative, who termed any deviation, any eccentricity insanity. In Séllei's interpretation they represent the 'lawgiver,' 'normimposer' dominant culture, the "Law of the Father," which Woolf did not obey, but escaped back into the preOedipal, semiotic stage. She keeps on exploring Woolf's ego constitution from this special point of view and seems to find the "root of both her art and her madness," her strong attachment to women and the reason for her social feminism in her personal psychological development. Séllei concludes her train of thought with the summary of differences between the two writers' image of their own womanhood: "Mansfield's search for identity was predominantly masculine, characterised by fatherorientation in the Oedipal and Symbolic, adopting the model's dominant culture, thus a feminine discourse [in Showalter's term it means the imitation and adoption of the dominant mode]; whereas in Woolf's case mother-identification played the more significant role, so her discourse was more disruptive, informed by the nonacceptance of the dominant discourse" (in Showalter's term the female phase) (82).

In the second part of her study, entitled "Mansfield and Woolf," Séllei sets out to compare the two women's aesthetic concepts, mainly in an indirect way, as Mansfield did not form her views on literature into separate essays; they can be found in her Journal, letters and reviews. Séllei, on one hand, relies on their respective opinions of Dorothy Richardson's stream of consciousness novel sequence Pilgrimage, outlined in their reviews of the book, and their reception of each other's work, on the other. The author limits her investigation to Mansfield's reviews and opinions of Woolf's Night and Day and "Kew Gardens" and to Woolf's views, public and private, on Mansfield's "Bliss" and "Prelude". According to Séllei, these critical remarks reveal "the extent to which Katherine Mansfield and Virginia Woolf had, indeed, 'the same job,' as well as the aspects in which they were so antagonistically opposed." (18)

Although Mansfield's review of Woolf's Night and Day was not an open attack, her description of the novel as "Jane Austen up-to-date" offended Woolf. She condemned it for 
its narrative technique, the omnipresent narrator who describes and controls the characters and never lets them speak for themselves. Séllei also points out the ethical dimension of Mansfield's review: she thinks that "the universe of the novel conveys a sense of security, which, in a post-war atmosphere, is a betrayal of art." (96)

In the following chapter Séllei goes on to describe Mansfield's ideas concerning the function of writing, technique, organisation and construction. The new perspectives behind everyday reality can be revealed, in Mansfield's opinion, in a moment "of direct feeling when we are most ourselves and least personal" (100), which Séllei compares to the Joycean epiphany. In these moments, which have an organising effect in her stories, subjectivity and objectivity are intertwined. No wonder she rejected Dorothy Richardson's The Tunnel (the first volume of her experimental novel series, The Pilgrimage) which, she thinks, lacks any kind of organising principle and is "composed of bits, fragments, flashing glimpses, half scenes, whole scenes, all of them quite distinct and separate, and all of them of equal unimportance" (Mansfield quoted by Séllei, 100); it is a typical example of, what she calls, "the notebook literature of our day." According to Mansfield, despite the technical perfection Richardson most certainly achieved, her novel remains marginal, because "she lost sight of the function of literature: that it should retain its meaningfulness to the reader, and should not turn absolutely inward and be self-reflective." (104) Although Virginia Woolf's review of Richardson's novel is not unanimously appreciative, she finds Richardson's stylistic and theoretical achievement remarkable, and as Séllei points out, Woolf and Richardson are on common ground concerning, for example, the representation of the characters' consciousness. The comparison of their different evaluation of Richardson's novel also indicates the difference between their relationships towards the female tradition, and the author thinks that "the stance they take is also invariably expressive of their womanhood," and "the motivation for these different positions can certainly be found in their dissimilar gender constitutions." (108) What Woolf praises in Richardson's novel Revolving Lights, "the psychological sentence of the feminine gender," corresponds with her own ambitions to create "a woman's sentence." It reveals Woolf's language-oriented 'female aesthetics,' which Séllei calls 'feminine textuality.' Mansfield's approach is thematic ('thematic femininity,' in Séllei's term), "her target was to con- 
vey a specifically feminine vision of life," (110) but her stories do not offer stylistic innovations, which she rejected as "sheer technicality" in Richardson's novels. Mansfield, in her review of "Kew Gardens" emphasises the existence of all those elements that she most misses in Richardson's novel: coherence, interdependence of details, and its point of view technique. Mansfield seems to have detected the 'new mould' she was also looking for in the narrative of "Kew Gardens" and she especially appreciated the author's 'indifferent' attitude as opposed to the author's omnipotence in Night and Day. Although Woolf was hurt by Mansfield's review of her novel, she always appreciated Mansfield's views of literature and they also influenced her further work.

Mansfield did not remain unaffected by Woolf's aesthetic principles, either. In the chapter entitled "The detached existence of a work of art" Séllei compares the two versions of Katherine Mansfield's short story: The Aloe, which Mansfield offered for Hogarth Press publication on Woolf's request in 1917, and the rewritten version, which came out entitled "Prelude" in 1918. Séllei suggests that the alterations were initiated by Woolf and she demonstrates her idea by thoughtful close reading of the two stories. She concludes that the omis- sions, changes in grammatical structures, punctuation, chapter construction and the narrative technique "brought about a thematically and stylistically more coherent short story, which, while remaining typical of Mansfield's style and concerns, could satisfy also Woolf's critical expectations, laid down in 'Modern Fiction." (114) In "Prelude" by shifting from one consciousness to another, Mansfield managed to present a series of visions of life in a new and unique form. She gave up her main structural device, the epiphany and replaced it by 'minor illuminations,' which can be compared to Woolf's favourite method, the reverie. Consequently Woolf's opinion was basically positive, she thought "Prelude" "has the living power, the detached existence of a work of art" (125). Nevertheless, she found fault with "Prelude" as well: she still maintained her main objection to all of Mansfield's writing, that is, she condemned its 'cheap realities.' Her rejection of "Bliss" had the same basis, but she extended it to the whole work. Séllei goes on to investigate the background to Woolf's ambivalent evaluation and again, seems to find the answers in their different psychological construction, "in their attitude to their womanhood, and to the expression of women's experiences in fiction." (126) To support her hypothesis 
she gives a thorough analysis of "Bliss" and also compares the themes and structures of the two stories. In her interpretation she uses the terminology and ideas of feminist psychoanalytic theories basing her study of the protagonist's character on Adrienne Rich's concept of motherhood as experience and institution. In both stories Mansfield uses the point-of-view technique, so the technical and the thematic resemblance should have encouraged a similar evaluation, yet Woolf disliked "Bliss." To explain this 'paradox' Séllei turns to Woolf's essays on Jane Eyre and Wuthering Heights, in which she seems to detect the same contradiction. Woolf preferred Emily Bronte's novel, because contrasted with Charlotte Bronte's novel "there is no ' $\mathrm{I}$ ' in Wuthering Heights. [...] The impulse which urged her to create was not her own suffering or her own injuries. She looked upon a world cleft into gigantic disorder and felt within her the power to unite it in a book." (144) Woolf condemns the 'angry' first person singular female narration in Jane Eyre, which, Séllei points out, is the technique of "Bliss," too, while in Wuthering Heights, like in "Prelude," the perspective is multiple. Another possible reason for Woolf's discriminative judgement of "Bliss" is its more conventional structure with a climax at the end, which creates the traditional effect of fixity and wholeness.

In the "Conclusion" of the book Séllei sums up the essence of Katherine Mansfield's and Virginia Woolf's antagonistically different writing strategies which also led to personal disagreements. Behind the professional differences Séllei sees their different 'psychosocial development.' Woolf 's "boundlessly flowing feminine sentence" betrays her unfixed ego boundaries, "her concept of androgyny, on the other hand, shows traits of the suppressive effect of a male hierarchy she could never get rid of." (147) Séllei agrees with Rich that Woolf suppressed her anger in a fear of male criticism, and sublimated her femininity into "sentence pattern and fiction structure." (148) Mansfield, on the other hand, in her efforts to maintain her independence and individuality, identified with the dominant, the symbolic, and in consequence, "in her fiction she preserved more focus, more fixity, which corresponds with her more fixedly structured ego boundaries and separate individuality." (148) Thematically, however, she is more gender conscious than Woolf, trying to "tell the truth about her own experiences as a body." That is why, Séllei thinks, Mansfield has never been accepted by the dominantly male criticism. In Séllei's opinion true and 
equal recognition of both writers came with recent feminist writing and criticism. She interprets Luce Irigaray's statement, "if we don't invent a language, if we don't find our body's language, its gestures will be too few to accompany our story" as a testimony to Woolf's language, which provides the framework for Mansfield's "story of a self-conscious sex."

In her fresh, thorough and most interesting study - especially in its first part - Nóra Séllei has "tried to make a portrait" of Katherine Mansfield and Virginia Woolf "almost as a novelist might make a character in fiction." ${ }^{3}$ The characters of the two 'protagonists' are often reflected in their relationship, and their characters, or rather 'ego constitutions' - the term used in the study - define this bond. ${ }^{4}$ Séllei's psychoanalytic ap-

\footnotetext{
${ }^{3}$ Virginia Woolf about 'recreating' Fry's figure in her preface to her "Impressions of Roger Fry," in: The Virginia Woolf Manuscripts: From the Henry W. and Albert A. Berg Collection at The New York Public Library. $2135 \mathrm{~mm}$ microfilm reels. (Reading: Research Publications International, 1994)

${ }^{4}$ Elisabeth Abel describes the friendship of women characters in similar terms: "through the intimacy which is knowledge, friendship becomes a vehicle of self-definition for women, clarifying identity through relation to an other who embodies and reflects an essential aspect of the self"
}

proach is based on mother-daughter bonding, which, according to J.K. Gardiner, "encourage critics to investigate relationships among women, [...] both outside and inside texts' fluid margins." ${ }^{5}$ The theory (of motherdaughter relationship), however, does not stay in the background in Séllei's book: the author seems to suggest a parental hierarchy in the two writers' relationship by assigning the role of 'surrogate' mother, or that of an elder sister who takes over mother's duties, to Woolf. Having described the increase of Mansfield's 'depression' and 'feeling of loss' after her mother's death, with whom her relationship "had never been absolutely harmonious," she goes on to say that in consequence "Virginia's presence became more and more vital." (42) Séllei also points out Woolf's motherly attitude by emphasising that she frequently visited Mansfield "to alleviate the pains of a woman and a writer who was seven years her junior" (italics added) (42). This implied 'mother-

in: E. Abel: "(E)merging Identities: The Dynamics of Female Friendship in Contemporary Fiction by Women" (Signs, 6, 3, 1981, 413-35).

5udith Kegan Gardiner, "Mind mother: psychoanalysis and feminism" in: Gayle Greene and Coppélia Kahn (eds.): Making a Difference: Feminist Literary Criticism (London and New York: Routledge, 1985, 1991, 113-145), 136. 
daughter' bond between 'Virginia' and 'Katherine' is a personal attachment (outside texts' fluid margins), ${ }^{6}$ but later, in the second part of the study, it is implicitly extended onto the professional bond, too. Séllei suggests that the alterations Mansfield made in her short story The Aloe - which resulted in "Prelude" - were not simply proposed by Woolf, but also influenced by her aesthetic principles, although there is no written evidence of this. Both suppositions, despite their convincing argumentation, are rather speculative, thus they are also a part of the fictitious world of - Séllei's book (inside texts' fluid margins). ' 'Inside merges with outside' in other respects, too: the psychology of the two women determined the kind of prose they wrote and also their views of each other's work. Séllei puts down Woolf's innovations in language, her "boundlessly flowing feminine sen-

${ }^{6}$ The author uses the writers' first names in the first part, which strengthens the impression of their being fictitious characters - we are 'inside the text's fluid margins.' On the other hand, the author deploys 'facts,' original 'documents' to support her ideas - we are also 'outside the text's fluid margins.'

7The analogy of maternity can be - could have been - played out on several other levels, too: in connection with the writers' relationship with their texts and characters, for example. tence" to her "unfixed ego boundaries,' which in turn is the result of her "troubled relationship with her parents," and her "childhood sexual abuse." (147) Mansfield's fiction, which preserves "more focus, more fixity," on the other hand, "corresponds with her more fixedly structured ego boundaries and separate individuality." (148) Such reductive statements tend to weaken her otherwise engaging and stimulating theme. Her analyses of the literary works are fascinating, although when she starts applying the terms of different feminist discourses (Rich, Chodorow, Kristeva, Cixous) the pattern becomes somewhat predictable.

There is one (more) point where I would like to take issue with the author: the evaluation of Woolf's concept of androgyny. Séllei perpetuates the traditional misinterpretation of early feminist criticism, especially that of Showalter, who saw the 'sexless' state of the androgynous writer as "an escape from the confrontation with femaleness or maleness," from "personal identity, from the claims of the self to be expressed." Showalter also suggests that Woolf's awareness - and fear - of a male audi-

\footnotetext{
${ }^{8}$ Elaine Showalter: $A$ Literature of their Own. British Women Novelists from Bronte to Lessing. (Princeton: Princeton UP, 1977), 289-290.
} 
ence contributed to her rapprochement of expressing anger and protest in art. Séllei continues in the same vein, connecting this latter argument the fear of the dominant male opinion - to her theory about the effects of Woolf's childhood experience of male violence. She also argues that the concept of androgyny "worked well" and contributed to Woolf's acceptance in the literary canon by the predominantly male criticism and seems to suggest that Mansfield was rejected because of her unwillingness to make up a similar 'camouflage.' Woolf was undoubtedly "conscious of," and even anxious about "being overheard by men," as her diary entries at the time of the publication of $A$ Room of One's Own show, but I do not think it should be seen as a motivation for her concept of androgyny. Toril Moi as

\footnotetext{
9"It is a little ominous that Morgan [E.M. Forster] won't review it. It makes me suspect that there is a shrill feminine tone in it which my intimate friends will dislike. I forecast, then, that I shall get no criticism, except of the evasive jocular kind, from Lytton [Strachey], Roger [Fry] and Morgan; that the press will be kind and talk of its charm and sprightliness; also I shall be attacked for a feminist and hinted at for a Sapphist;" in: Leonard Woolf (ed.): A Writer's Diary: Being Extracts from the Diary of Virginia Woolf (London: The Hogarth Press, 1954) 148.
}

early as 1985 pointed out the flaws in Showalter's argumentation. She sees Woolf's theory not as a method for fleeing gender identities, but as a deconstruction of "the death-dealing binary oppositions of masculinity and femininity." ${ }^{10}$ Possibly Pamela Caughie's excellent study (1991) came too late for the author - in her investigation of androgyny in Orlando she goes even further saying that androgyny reflects not only a sexual ambiguity, but a textual one as well. While Showalter condemns Woolf's theory for its ambivalence, its avoiding strategy to take position, Caughie praises it for its "refusal to choose." In her view, the androgynous vision is "paratactical, not dichotomous," which "affirms a 'fertile oscillation' between positions." 11 Many other recent feminist studies deal with Woolf's concept of androgyny in similar terms. ${ }^{12}$ But we may as well take

${ }^{10}$ Toril Moi: Sexual/Textual Politics: Feminist Literary Theory (London and New York: Routledge 1985, 1991), 13.

${ }^{11}$ Pamela L. Caughie: Virginia Woolf and Post. modernism. Literature in Quest and Question of Itself (Urbana and Chicago: University of Illinois Press, 1991), 82.

${ }^{12}$ see, for example, Rachel Bowlby: Virginia Woolf: Feminist Destinations (Oxford: Basil Blackwell, 1988), Rachel Blau DuPlessis: Writing Beyond the Ending (Bloomington: Indiana University Press, 1985), Marianne DeKoven: 
Woolf's original intention seriously and look at androgyny as a concept of artistic creation, an ideal, which she tried to realise in her novels. What is manifested in this ideal is the artist's longing to restore primordial unity, at least in creation, in an age of final fragmentation. The artist figures in Woolf's novels - Lily Briscoe in To the Lighthouse or Bernard in The Waves, for example, - struggle to combine the feminine and masculine modes of perception, which is the precondition of the creative act for them. The result is a kind of balance in which neither principle is prevalent, nor are they fused into one, but are simultaneously present in a state of androgyny. A comparison of Woolf's androgyny with other writers' concepts of artistic creation in the same period would help one place it in a much wider context and see its importance in the modernist paradigm.

Naturally Séllei's feminist context does not allow such diversions; its coherent feminist discourse, if it is not a contradiction in terms, is one of the many merits of the book. The consequent and convincing combination of the two women writers' biographies and works, and the excellent and engaging style also contribute to the 'reader-friendly' attitude that this study represents among other academic works. The author's clever arguments do not lack a woman's intuition, either, and it helps her get close to her material, reach "intimacy itself, which is knowledge." 13
Rich and Strange: Gender, History, Modernism (Princeton: Princeton University Press 1991), Makiko Minow Pinkney: Virginia Woolf and the Problem of the Subject (Brighton, Sussex: Harvester Press, 1987)

\footnotetext{
13" for it was not knowledge but unity that she desired, [...] nothing that could be written in any language known to men, but intimacy itself, which is knowledge." in: Virginia Woolf: To the Lighthouse (London: Grafton Books, 1995), p. 58.
} 